\title{
Effects of vineyard coverage and extent on benthic macroinvertebrates in streams of Northern California
}

\author{
Justin E. Lawrence*, Matthew J. Deitch and Vincent H. Resh \\ Department of Environmental Science, Policy, and Management, University of California, Berkeley, CA 94720-3114, USA
}

Received 20 October 2010; Accepted 1 June 2011

\begin{abstract}
Vineyards are a dominant feature of many landscapes in Mediterranean-climate regions. We examined the effects of streamflow declines, associated with vineyard water-withdrawals for frost protection, on benthic-macroinvertebrate communities at three sites along three small streams in the Mediterraneanclimate region of Northern California. One site was heavily affected by water withdrawals for frost protection, the other two were not. In addition, we examined relationships between vineyard coverage and benthicmacroinvertebrate community response using data from 59 sampling events at 39 sites along 35 small streams in Napa County, California. We tested three a priori hypotheses in terms of the response of biological traits of benthic macroinvertebrates to high vineyard coverage: (1) proportion of individuals with semi-voltine (i.e., one generation every 2 years) life cycles would be lower compared to those with uni- and multi-voltine cycles, (2) proportion of individuals able to undergo diapause would be higher, and (3) proportion of individuals with the ability to burrow into the substrate would be higher. In the three-site study, we found that vineyard water-withdrawals for frost protection coincided with consistently lower values in both the benthic-macroinvertebrate index of biotic integrity (B-IBI) developed for Northern California streams and the ratio of Ephemeroptera-Plecoptera-Trichoptera to Odonata-Coleoptera-Hemiptera individuals (EPT/OCH), a metric developed for European Mediterranean streams. In the broader-scale study, we observed that vineyard-coverage levels above about $20 \%$ coincided with lower values of the B-IBI. The semi-voltine life-cycle trait was lower above this level, whereas the diapause and burrowing traits were not affected.
\end{abstract}

Key words: Vineyards / frost protection / water withdrawals / benthic macroinvertebrates / biological monitoring

\section{Introduction}

The growing of grapes for wine production has been done in Mediterranean-climate regions for millennia. However, grape vines in these regions are susceptible to tissue damage when air temperatures are low. In northern-hemisphere Mediterranean-climate regions, low-temperature injuries most commonly occur in spring months, during the period of bud development, when air temperatures drop below a level of about $-0.5{ }^{\circ} \mathrm{C}$ (Kasimatis and Kissler, 1974). Vineyards use different methods for frost protection in spring months, including vineyard-site selection, grape-variety selection, cultural practices, wind circulation, heaters, and water sprinklers (Kasimatis and Kissler, 1974; Johnson and Howell, 1981; Donaldson et al., 1993). Water-sprinkers are used on about $9 \%$ of the total irrigated vineyard-land in California (Orang et al., 2008).

\footnotetext{
*Corresponding author: jlawrence@berkeley.edu
}

Use of water sprinklers for frost protection has been observed repeatedly to drastically reduce streamflow in small streams in the Mediterranean-climate region of Northern California (Deitch et al., 2009). These reductions typically occur between the months of March and April (Deitch et al., 2009), which coincides with the end of the rainy season in this region (Gasith and Resh, 1999). This time period is very important for the resident benthic macroinvertebrates because it is when the majority of preemergence growth occurs (Mendez and Resh, 2008).

The effects of reductions in streamflow associated with vineyard water-withdrawals for frost protection on the abundance and composition of benthic-macroinvertebrate communities have not been explored in other studies. However, many studies have shown a strong relationship between streamflow reductions and benthic response in Mediterranean-climate streams (Bonada et al., 2006, 2007a, b; Tornés et al., 2007; Morais, 2008). Furthermore, prolonged drought in Mediterranean-climate regions has particularly strong effects on the abundance and 
composition of benthic-macroinvertebrate communities in small streams (Bêche et al., 2006; Bêche and Resh, 2007a, b). Water diversions during these drought periods further increase the physical stress on these communities (Gasith and Resh, 1999).

Streamflow reductions associated with frost protection could also have a selective effect on biological traits among taxa in benthic-macroinvertebrate communities. The biological traits for a given taxon may include, for example, the number of generations per year, the ability to enter a state of diapause, and the ability to burrow into the streambed to obtain food, seek refuge from predators, or escape low-flow conditions (Bêche and Resh, 2007a, b). Biological traits of benthic-macroinvertebrate communities in Mediterranean-climate regions have been shown to be affected by long-term climate variability (Bêche et al., 2006; Bêche and Resh, 2007a, b; Bonada et al., 2007a, b; Lawrence et al., 2010) and seasonal differences (Mouthon and Daufresne, 2006; Cordellier and Pfenninger, 2008; Spooner and Vaughn, 2008; Clausnitzer et al., 2009; Hering et al., 2009).

The objectives of this study are to determine whether: (1) vineyard water-withdrawals for frost protection affect benthic-macroinvertebrate communities; (2) there is a level of vineyard coverage above which the effects are more pronounced; and (3) exceeding this level has any effect on a priori selected biological traits. These questions have implications for evaluating the effects of vineyard coverage and extent on streams in Northern California and perhaps may suggest ideas for research on this topic in other Mediterranean-climate areas.

\section{Materials and methods}

\section{Study sites and benthic-macroinvertebrate data}

This study is based on two benthic-macroinvertebrate datasets from the wine-growing region of Northern California. The first dataset includes benthic-macroinvertebrate samples collected intensively over time. It is used to examine change in benthic-macroinvertebrate communities occurring over 2 years (2004-2005) in three sites along three small streams (Franz Creek, Bidwell Creek, and Maacama Creek; Fig. 1) in Sonoma County, California, from just-before to just-after the period of water withdrawal for frost protection. The watershed areas of these sites ranged from 13 to $106 \mathrm{~km}^{2}$ and the vineyard coverage upstream of the sites ranged from 6 to $14 \%$ of the watershed area. In Northern California, this frost-protection period can occur anytime from midFebruary to mid-May depending on the climate patterns of the year (Smith et al., 2004).

The effect of water withdrawals for frost protection on streamflow differed among the three streams examined (Deitch et al., 2009). In 2005, when the most complete streamflow records were kept at the three sites, the reduction of streamflow observed was by far the highest in Franz Creek (Tab. 1). The reduction in streamflow was
$>75 \%$ in Franz Creek on six occasions over the 2 years of the study, whereas the reduction in streamflow never surpassed this $75 \%$ level in either of the other two streams examined (Deitch et al., 2009). The highest magnitude changes in streamflow associated with a single frostprotection event were 530 L.s ${ }^{-1}$ in Franz Creek and 120 L.s ${ }^{-1}$ in Bidwell Creek (Deitch et al., 2009). At Maacama Creek, the highest magnitude change in streamflow associated with a single event was lower than at both Franz Creek and Bidwell Creek. However, the exact amount of change could not be determined because the vineyards in the watershed above Maacama Creek are located farther from the sampling site and, as a result, the change in streamflow was extended over a relatively long time-span (Deitch et al., 2009). Vineyard waterwithdrawals for frost protection at these sites began in mid-March and extended into mid-April each year during this study. For more detailed information on the dates, magnitude, and duration of the associated streamflow declines, see Deitch et al. (2009).

Benthic macroinvertebrates were sampled at these three sites from a fixed area of $0.09 \mathrm{~m}^{2}$ in individual riffles using a D-frame kicknet with a mesh size of $500 \mu \mathrm{m}$, which is by far the most common mesh size used by state agencies in the United States (Carter and Resh, 2001). Sampling began in early March and extended into early May each year, and included one kick-net sample per riffle per sampling event. All taxa in these samples were identified to genus. All sampling was done by the same individual (M. Deitch) and all identifications were done by the same individual (J. Lawrence).

The second dataset contains samples collected intensively over the major wine-growing area of California. It is used to examine differences in benthic-macroinvertebrate communities among 39 sites along 35 streams in Napa County, California (Fig. 1). Twenty of these 39 sites were sampled in both the years 2000 and 2001, and the other 19 sites were sampled in only one year, either 2000 or 2001 , for a total of 59 sampling events. The sites were unique in that they had different levels of vineyard coverage in the watershed upstream of each site, which is described as $\%$ of land cover. The watershed areas of these sites ranged from 1 to $209 \mathrm{~km}^{2}$ and the vineyard coverage ranged from 0 to $76 \%$. Four sites were located on the same stream, and a fraction of the sites were located in the same sub-basins of the watershed, so the sites were not totally independent (Fig. 1).

Benthic-macroinvertebrate samples were collected by the Friends of the Napa River as part of a locally organized, biological-monitoring effort. Collections were made in mid-April following the standard, targeted-riffle approach of the California SWAMP bioassessment protocol (Ode, 2007). Three replicates were collected, each taken from a fixed area of $1.8 \mathrm{~m}^{2}$ using a net with a mesh size of $500 \mu \mathrm{m}$ (as specified in the protocol). Each of the three replicate samples from a site were sub-sampled for a minimum of 300 macroinvertebrates and all organisms were identified to genus level by Aquatic Biology Associates Inc., Corvallis, Oregon. 


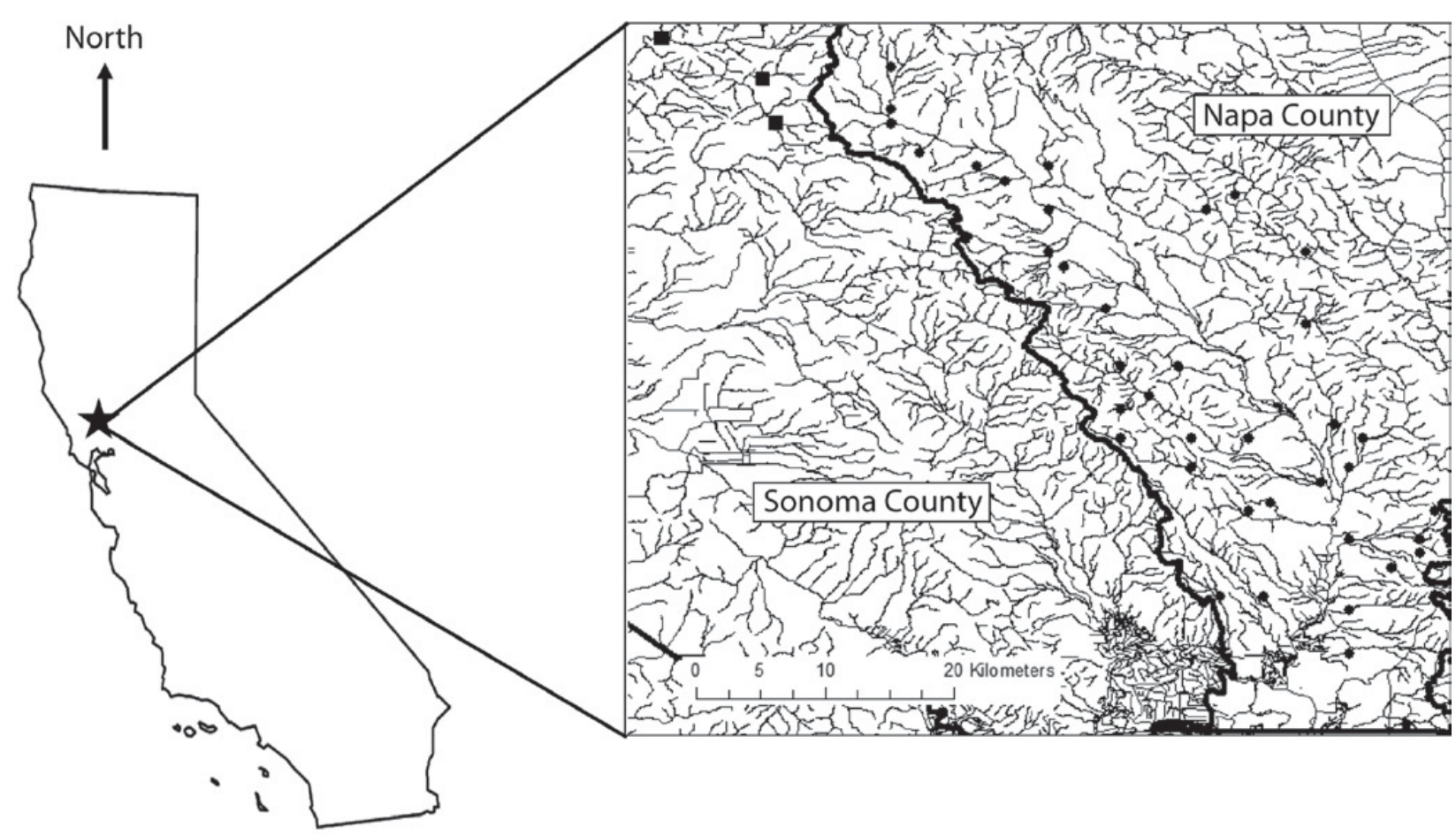

Fig. 1. Map showing the three sites where benthic macroinvertebrates were collected over the period extending from just before to just after water withdrawals by vineyards for frost protection (squares), and the 39 sites with varying levels of vineyard coverage (circles); the thick black lines are California county boundaries and the thin black lines are waterways in the drainage network.

Table 1. Number of drying events, median reduction of streamflow associated with water withdrawals as a percent of initial flow, and lower and upper quartiles of percent reduction associated with withdrawals at Franz, Bidwell, and Maacama Creek field sites in the year 2005 (from Deitch et al., 2009).

\begin{tabular}{lcccr}
\hline Site & $\begin{array}{c}\text { Number of } \\
\text { drying events }\end{array}$ & $\begin{array}{c}\text { Median reduction } \\
\text { of flow }(\%)\end{array}$ & $\begin{array}{c}\text { Lower quartile of } \\
\text { flow reduction (\%) }\end{array}$ & $\begin{array}{c}\text { Upper quartile of } \\
\text { flow reduction }(\%)\end{array}$ \\
\hline Franz & 7 & 78 & 45 & 80 \\
Bidwell & 5 & 15 & 12 & 24 \\
Maacama* & 3 & 0 & 0 & 0 \\
\hline
\end{tabular}

* Streamflow reduction in Maacama Creek was detected relative to an upstream gauge to illustrate reduced flow on a tributary to Maacama Creek (where flow in the tributary equaled approximately zero for three separate events).

\section{Evaluating the effects of vineyard water withdrawals for frost protection}

We calculated five biological metrics from the benthicmacroinvertebrate data including the North Coast B-IBI (Rehn et al., 2005), total taxa richness, total abundance, $\%$ EPT individuals, and EPT/OCH richness, which is an index proposed for Mediterranean-climate streams by Bonada et al. (2006). The North Coast B-IBI is composed of eight metrics, which include EPT richness, Coleoptera richness, Diptera richness, \% intolerant individuals, \% non-Gastropoda scraper individuals, $\%$ predator individuals, \% shredder taxa, and \% non-insect taxa (Rehn et al., 2005). We calculated values for these metrics from samples collected from a single sampling event just before water withdrawals for frost protection occurred (early March) and just after (late June), and examined the change in the metric values separately for each year.
To determine whether there is a level of vineyardcoverage above which the effects of vineyards are more pronounced, we calculated values of the North Coast B-IBI for all of the sampling events and examined the values across the range of vineyard coverage observed. We first plotted these B-IBI values against \% vineyard coverage to examine possible changes that occur over a certain vineyard coverage. After determining this we then calculated the average, range, and standard deviation of the final B-IBI values above and below the selected vineyard coverage, and did the same for each of the eight component metrics of the B-IBI. To determine whether the level chosen was statistically significant, we compared the metric values above and below the level using MannWhitney Rank Sum Test. The a priori hypothesis was that the average value of the B-IBI would be higher for sites below than for those above the level chosen because the B-IBI was designed to detect land-use effects by reflecting 
Table 2. Comparison of biological metric values just before and just after the period of water-withdrawals for vineyard frostprotection.

\begin{tabular}{|c|c|c|c|c|c|c|}
\hline \multirow[b]{2}{*}{ Site } & \multirow[b]{2}{*}{ Metric } & \multicolumn{2}{|c|}{2004} & \multicolumn{2}{|c|}{2005} & \multirow[b]{2}{*}{ Trend } \\
\hline & & $\overline{\text { Pre-Withdrawal }}$ & Post-withdrawal & $\overline{\text { Pre-withdrawal }}$ & Post-withdrawal & \\
\hline \multirow{5}{*}{ Franz Creek } & North Coast B-IBI & 48 & 40 & 42 & 32 & Decrease \\
\hline & Total richness & 7 & 14 & 13 & 13 & Unclear \\
\hline & Total abundance & 33 & 207 & 136 & 399 & Increase \\
\hline & $\%$ EPT individuals & 91 & 56 & 93 & 53 & Decrease \\
\hline & EPT/OCH individuals & 30 & 4 & 32 & 8 & Decrease \\
\hline \multirow[t]{5}{*}{ Bidwell Creek } & North Coast B-IBI & 39 & 46 & 23 & 29 & Increase \\
\hline & Total richness & 8 & 14 & 7 & 15 & Increase \\
\hline & Total abundance & 5 & 343 & 84 & 165 & Increase \\
\hline & $\%$ EPT individuals & 90 & 72 & 50 & 46 & Decrease \\
\hline & EPT/OCH individuals & 66 & 9.5 & 42 & 77 & Unclear \\
\hline \multirow[t]{5}{*}{ Maacama Creek } & North Coast B-IBI & 41 & 45 & 34 & 29 & Unclear \\
\hline & Total richness & 7 & 18 & 7 & 14 & Increase \\
\hline & Total abundance & 27 & 149 & 21 & 307 & Increase \\
\hline & $\%$ EPT individuals & 96 & 45 & 71 & 72 & Unclear \\
\hline & EPT/OCH individuals & 26 & 4.4 & 3 & 7 & Unclear \\
\hline
\end{tabular}

higher levels of disturbance with lower B-IBI values (Rehn et al., 2005).

\section{The relationship between vineyard coverage and biological traits}

Three biological traits of benthic macroinvertebrates (voltinism, resistance to desiccation, and locomotion abilities) that were hypothesized a priori to be most likely to show an impact associated with water withdrawals were chosen, using information presented in Bêche et al. (2006). Only three traits were examined rather than choosing a large number of traits because this limited approach has been advocated in the literature as a potentially more informative method, given the confounding nature of trade-offs among traits, especially in these streams where traits for responding to both flooding and drying would be selected for (Poff et al., 2006).

We focused on specific categories within these traits: (1) the presence of a semi-voltine (i.e., generation times lasting longer than 1 year, compared to the one generation per year of the uni-voltine and the many generations per year of the multi-voltine) life cycle, (2) diapause (i.e., the ability to enter a period of suspended growth and development in response to environmental stress), and (3) burrowing ability (i.e., taxa that can dig down into the stream bottom to find food, refuge from predators, and shelter during low streamflow). The a priori hypotheses were that above a certain vineyard coverage level there would be proportionally (1) fewer semi-voltine (i.e., long-lived) taxa, (2) more taxa that undergo diapause, and (3) fewer taxa that burrow into the substrate.

The distribution of biological traits among taxa was calculated using abundance data for taxa with these traits. The traits for all taxa present in each sample and the proportional representation of each trait category were determined based on descriptions used by Bêche et al. (2006). Because the fuzzy-coding approach was used (Chevenet et al., 1994), each taxon could be described using a fractional composition of multiple trait categories. For example, a taxon could be described as 0.4 semivoltine and 0.6 bi-voltine, with the fractions summing to 1.0 , which would indicate that this taxon has partial semi-voltine and partial bi-voltine characteristics, and be expressed in terms of relative abundance.

\section{Results}

\section{Relationship between vineyard water-withdrawals for frost protection and macroinvertebrates}

The site-specific, 2-year study conducted at three sites revealed a decrease in the value of the North Coast B-IBI and in the ratio of EPT to $\mathrm{OCH}$ individuals in the stream most impacted by water withdrawals for frost protection (i.e., Franz Creek) during the 3-month frost-protection period in both years of the study (Tab. 2). However, there was variability in metric values within this time (Fig. 2). In one of the other streams (Bidwell Creek), the value of the B-IBI consistently increased during this time in both years, and in the other stream (Maacama Creek) there was no consistent trend (Tab. 2). In neither Bidwell Creek nor Maacama Creek were any consistent trends observed in the ratio of EPT to $\mathrm{OCH}$ individuals. Genera that disappeared or were strongly reduced in density after the hydrologic disturbance in Franz Creek and that resisted in the two other streams included Drunella (Ephemeroptera: Ephemerellidae), Epeorus (Ephemeroptera: Heptageniidae), and Gumaga (Trichoptera: Sericostomatidae).

\section{The effect of vineyard coverage on benthic macroinvertebrates}

An examination of the B-IBI scores at different levels of vineyard coverage suggests that the effects on benthic 

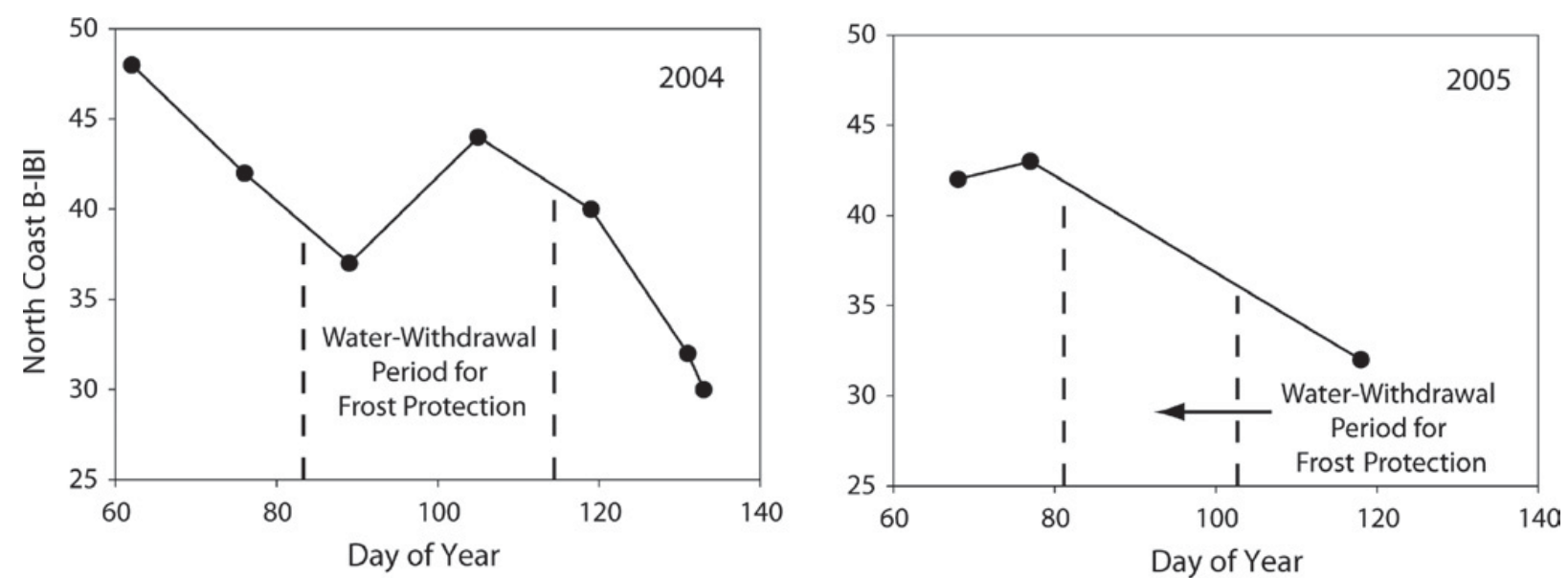

Fig. 2. Values of the North Coast B-IBI calculated from benthic macroinvertebrate samples collected from Franz Creek during the time-frame just before, during, and just after water withdrawals by vineyards for frost protection occurred in 2004 and 2005 .

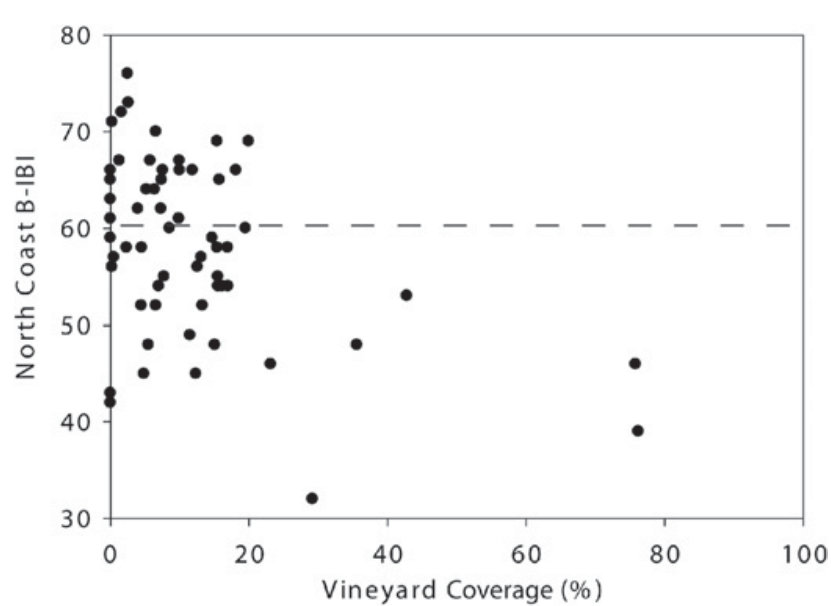

Fig. 3. The value of the North Coast B-IBI calculated from 59 benthic-macroinvertebrate samples collected from 39 sites with a range of vineyard coverage $(0-76 \%)$ in their upstream watersheds; the dotted line indicates the lower limit of "good" conditions for the North Coast B-IBI.

macroinvertebrates were more pronounced when coverage exceeded 20\% (Fig. 3). However, the relatively low number of sites sampled above this level is a limitation for drawing statistical inferences (i.e., 6 sampling events above $20 \%$ coverage versus. 53 sampling events below $20 \%$ coverage). This discrepancy in sampling is largely a result of the relative inaccessibility of sites with very high vineyard coverage because they are located on private land. However, despite the unbalanced collection of samples, the difference in the value of the B-IBI below and above $20 \%$ coverage was statistically significant (Tab. 3). Moreover, six of the eight component metrics of the B-IBI indicated a significant difference above and below $20 \%$ coverage when examined independently, including EPT richness, Coleoptera richness, Diptera richness, \% intolerant individuals, $\%$ non-gastropoda scraper individuals, and \% non-insect taxa (Tab. 3). The two component metrics that did not indicate a significant difference were $\%$ predator individuals and \% shredder taxa (Tab. 3).

\section{Relationship between vineyard coverage and biological traits}

There was some evidence for the occurrence of a lower percentage of individuals with the semi-voltine life-cycle trait above the $20 \%$ coverage level (Fig. 4). For example, the percentage of individuals with this life-cycle type ranged from 0 to $37 \%$ with a mean of $11 \%$ below $20 \%$ coverage and from 0 to $10 \%$ with a mean of $3 \%$ above $20 \%$ coverage. The difference between the median values of the groups above and below this level was statistically significant based on Mann - Whitney rank sum test $(P=$ $0.007)$. However, there was no evidence for a significant effect on the $20 \%$ coverage level on the diapause and burrowing traits.

\section{Discussion}

The biological effect that was observed in Franz Creek, i.e., the stream where the largest proportional reductions in streamflow occurred as a result of vineyard waterwithdrawals for frost protection (Fig. 2) is within the range for which the B-IBI was designed to detect (Rehn et al., 2005). It is highly likely that this effect was related to the water withdrawals for frost protection because a consistent decrease in the B-IBI was not observed in either of the other two streams where flow-reduction effects were much lower or non-existent (Tabs. 1 and 2). Likewise, the decrease in the EPT to OCH ratio in Franz Creek indicates that the stream system is shifting to a state that is increasingly dominated by pools as opposed to riffles (Bonada et al., 2006), which is consistent with the direction one would expect to be associated with a reduction in streamflow. A consistent decrease in the EPT to $\mathrm{OCH}$ ratio was not observed in the other two sites during the frost-protection period (Tab. 2), which provides further evidence that vineyard water withdrawals for frost protection are associated with the effect.

The apparent effects above $20 \%$ vineyard coverage that were evident from the B-IBI (Tab. 3, Fig. 3) represents 
Table 3. Comparison of biological metric values from streams above and below the $20 \%$ level of vineyard coverage in the 59 sampling events examined. Significant differences are indicated with an asterisk.

\begin{tabular}{|c|c|c|c|c|c|c|c|}
\hline \multirow[b]{2}{*}{ Metric } & \multicolumn{3}{|c|}{$\begin{array}{c}\text { Less than } 20 \% \\
\text { vineyard coverage }\end{array}$} & \multicolumn{3}{|c|}{$\begin{array}{l}\text { Greater than } 20 \% \\
\text { vineyard coverage }\end{array}$} & \multirow{2}{*}{$\begin{array}{c}\text { Significance } \\
P \text {-value }\end{array}$} \\
\hline & $\overline{\text { Average }}$ & Range & Std. Dev. & $\overline{\text { Average }}$ & Range & Std. Dev. & \\
\hline EPT richness & 26 & $6-41$ & 9 & 12 & $2-21$ & 6 & $0.002 *$ \\
\hline Coleoptera richness & 5 & $0-9$ & 2 & 2 & $0-8$ & 3 & $0.014 *$ \\
\hline Diptera richness & 27 & $16-37$ & 5 & 22 & $17-26$ & 4 & $0.021 *$ \\
\hline$\%$ Intolerant individuals & 39 & 4-84 & 19 & 15 & $2-25$ & 9 & $0.005^{*}$ \\
\hline$\%$ Non-gastropoda scraper individuals & 21 & $3-36$ & 9 & 10 & $3-16$ & 4 & $0.003 *$ \\
\hline$\%$ Predator individuals & 13 & 4-31 & 6 & 10 & $4-14$ & 4 & 0.430 \\
\hline$\%$ Shredder taxa & 17 & $11-29$ & 4 & 17 & $14-23$ & 3 & 0.679 \\
\hline$\%$ Non-insect taxa & 8 & $3-21$ & 4 & 13 & $5-25$ & 7 & $0.063 *$ \\
\hline North Coast B-IBI & 60 & $42-76$ & 8 & 44 & $32-53$ & 7 & $<0.001 *$ \\
\hline
\end{tabular}
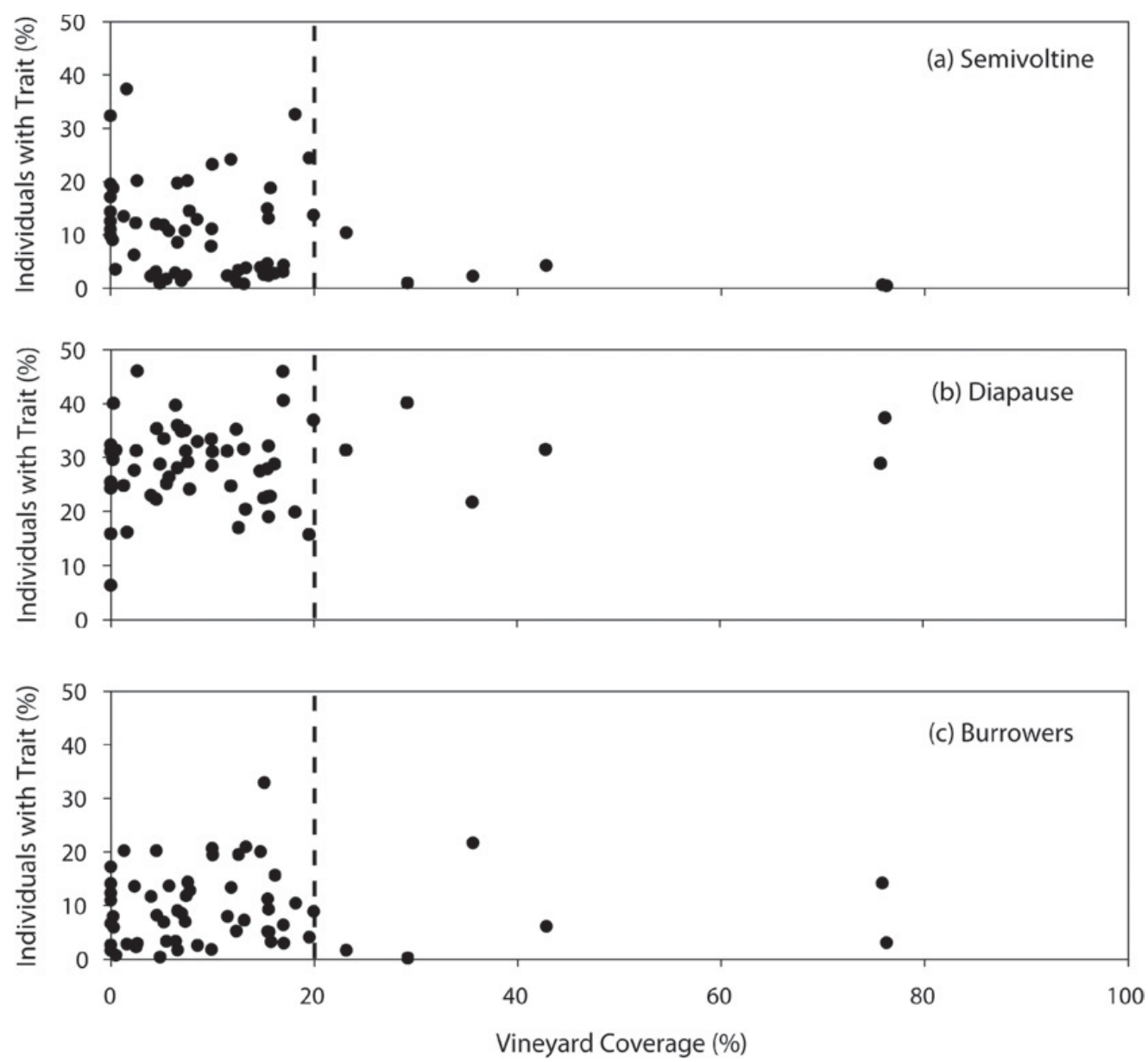

Fig. 4. Percent of individuals with specific biological traits that were hypothesized a priori to be responsive to water-level declines associated with water withdrawals by vineyards for frost protection; the $20 \%$ level of vineyard coverage is marked with a vertical, dotted line.

the level of vineyard development in Northern California above which a strong effect can be expected on benthicmacroinvertebrate communities. The maximum value of the B-IBI above $20 \%$ coverage was 23 points lower than the maximum value below it. None of the sampling events above $20 \%$ coverage had a B-IBI value indicative of "good" conditions according to Rehn et al. (2005), i.e., $\mathrm{B}-\mathrm{IBI}$ value $>61$, whereas $41 \%$ of the sites below $20 \%$ coverage did. The $\%$ shredders may have remained fairly constant across different levels of vineyard coverage because riparian corridors are maintained along streams in this region (Nicholls et al., 2001). These corridors may provide consistent litter input from trees that could supply a food source for shredders. The $\%$ predators may have remained constant because the predators could shift to a different prey as the community composition changed in response to different levels of vineyard development. 
The decrease in semi-voltine (i.e., long-lived) individuals above $20 \%$ coverage (Fig. 4 ) may relate to higher predation pressure or intolerance of lower flow and perhaps oxygen levels as a result of the sudden reductions in streamflow associated with the water withdrawals. These individuals would not be able to replenish their populations as quickly as individuals with shorter lifespans after these water-withdrawal episodes. The absence of a response in individuals with the trait that allows them to enter a diapause stage when exposed to unfavorable environmental conditions may relate to the short duration of the streamflow declines, which may not have been long enough to trigger diapause and thereby confer a selective advantage to these taxa. Furthermore, the absence of a response in burrowing individuals could relate to the presence of disconnected pools, which provide sufficient refuge during the streamflow declines to support individuals with other locomotive traits, such as the ability to fly, swim, and/or crawl.

A trend between water withdrawals associated with high vineyard coverage and benthic macroinvertebrates in the Mediterranean-climate region of Northern California was evident from this study, and the withdrawals appeared to affect aquatic habitats and biota. This water-withdrawal practice combined with other factors frequently associated with vineyards and agriculture in general (e.g., fertilizer and pesticide use, and/or increased erosion and sedimentation as a result of tillage) may impact benthicmacroinvertebrate communities and consequently their availability as food for higher trophic levels such as amphibians, fish, and birds.

However, flow has been observed to be the dominant driver of benthic-macroinvertebrate assemblage shifts in streams in the Mediterranean-climate region of Northern California (e.g., Bêche et al., 2006; Bêche and Resh, 2007a, b; Lawrence et al., 2010). As a result, it would override other variables. It is a limitation of this study that we did not measure other physical and chemical variables because this could have shed greater insight into the overall effect of vineyards on small streams. The effects of sedimentation on benthic macroinvertebrates in this region have been explored to a limited degree (Cover et al., 2008). Little is known about the effects of specific pesticides used by vineyards in this region on aquatic biota.

The impact of vineyards in the Mediterranean-climate region of Northern California may be particularly intense relative to other Mediterranean-climate regions around the world. In Northern California, the viticulture system is more of a monoculture than the systems in other Mediterranean, wine-growing regions. For example, in parts of Portugal and Spain the systems are characterized to a greater extent by small, family-owned farms (Altieri and Nicholls, 2002). Determination of whether effects above a certain level of vineyard development also apply to benthic macroinvertebrates in these regions may be a useful tool for management of riverine habitats and waterwithdrawal schemes in these areas. We suggest that future studies could begin by gathering new data and testing the applicability of the effects we observed above $20 \%$ vineyard-coverage in other wine-growing regions around the world.

Acknowledgements. We thank M. Matella for her assistance with vineyard-coverage calculations, L. Bêche for providing information on biological traits for specific genera, and M. Cover for his assistance in obtaining the macroinvertebrate data from the Friends of the Napa River. We also thank the US Department of Agriculture Forest Service under Cost Share Agreement No. 03-CR-11052007-042, the Edward A. Colman Fellowship in Watershed Management from the Department of Environmental Science, Policy, and Management at UC Berkeley, and the Pinto-Fialon Endowment administered by the Portuguese Studies Program (PSP) at UC Berkeley for support.

\section{References}

Altieri M.A. and Nicholls C.I., 2002. The simplification of traditional vineyard based agroforests in northwestern Portugal: some ecological implications. Agrof. Syst., 56, 185-191.

Bêche L.A., McElravy E.P. and Resh V.H., 2006. Long-term seasonal variation in the biological traits of benthic macroinvertebrates in two Mediterranean-climate streams. Freshw. Biol., 51, 56-75.

Bêche L.A. and Resh V.H., 2007a. Biological traits of benthic macroinvertebrates in California Mediterranean-climate streams: long-term annual variability and trait diversity patterns. Fundam. Appl. Limnol., 161, 1-23.

Bêche L.A. and Resh V.H., 2007b. Short-term climatic trends affect the temporal variability of macroinvertebrates in California 'Mediterranean' streams. Freshw. Biol., 52, 2317-2339.

Bonada N., Dolédec S. and Statzner B., 2007a. Taxonomic and biological trait differences of stream macroinvertebrate communities between Mediterranean and temperate regions: implications for future climatic scenarios. Global Change Biol., 13, 1658-1671.

Bonada N., Rieradevall M. and Prat N., $2007 \mathrm{~b}$. Macroinvertebrate community structure and biological traits related to flow permanence in a Mediterranean river network. Hydrobiologia, 589, 91-106.

Bonada N., Rieradevall M., Prat N. and Resh V.H., 2006. Benthic macroinvertebrate assemblages and macrohabitat connectivity in Mediterranean-climate streams of northern California. J. N. Am. Benthol. Soc., 25, 32-43.

Carter J.L. and Resh V.H., 2001. After site selection and before data analysis: sampling, sorting, and laboratory procedures used in stream benthic macroinvertebrate monitoring programs by USA state agencies. J. N. Am. Benthol. Soc., 20, 658-682.

Chevenet F., Dolédec S. and Chessel D., 1994. A fuzzy coding approach for the analysis of long-term ecological data. Freshw. Biol., 31, 295-309.

Clausnitzer V., Kalkman V.J., Ram M., Collen B., Baillie J.E.M., Bedjanic M., Darwall W.R.T., Dijkstra K.B., Dow R., Hawking J., Karube H., Malikova E., Paulson D., Schütte K., Suhling F., Villanueva R.J., von Ellenrieder N. and Wilson K., 2009. Odonata enter the biodiversity crisis debate: the first global assessment of an insect group. Biol. Conserv., 142, 1864-1869. 
Cordellier M. and Pfenninger M., 2008. Climate-driven range dynamics of the freshwater limpet, Ancylus fluviatilis (Pulmonata, Basommatophora). J. Biogeogr., 35, 1580-1592.

Cover M.R., May C.L., Dietrich W.E. and Resh V.H., 2008. Quantitative linkages among sediment supply, streambed fine sediment, and benthic macroinvertebrates in northern California streams. J. N. Am. Benthol. Soc., 27, 135-149.

Deitch M.J., Kondolf G.M. and Merenlender A.M., 2009. Hydrologic impacts of small-scale instream diversions for frost and heat protection in the California wine country. River Res. Appl., 25, 118-134.

Donaldson D.R., Snyder R.L., Elmore C. and Gallagher S., 1993. Weed control influences vineyard minimum temperatures. Am. J. Enol. Vitic., 44, 431-434.

Gasith A. and Resh V.H., 1999. Streams in Mediterranean climate regions: abiotic influences and biotic responses to predictable seasonal events. Ann. Rev. Ecol. Syst., 30, 51-81.

Hering D., Schmidth-Kloiber A., Murphy J., Lücke S., ZamoraMuñoz C., López-Rodríguez M.J., Huber T. and Graf W., 2009. Potential impact of climate change on aquatic insects: a sensitivity analysis for European caddisflies (Trichoptera) based on distribution patterns and ecological preferences. Aquat. Sci. Res. Bound., 71, 3-14.

Johnson D.E. and Howell G.S., 1981. Factors influencing critical temperatures for spring freeze damage to developing primary shoots on Concord grapevines. Am. J. Enol. Vitic., 32, 144-149.

Kasimatis A.N. and Kissler J.J., 1974. Responses of grapevines to shoot break-out following injury by spring frost. Am. $J$. Enol. Vitic., 25, 17-20.

Lawrence J.E., Lunde K.B., Mazor R.D., Bêche L.A., McElravy E.P. and Resh V.H., 2010. Long-term macroinvertebrate responses to climate change: implications for biological assessment in Mediterranean-climate streams. J. N. Am. Benthol. Soc., 29, 1424-1440.

Mendez P.K. and Resh V.H., 2008. Life history of Neophylax richeri (Trichoptera: Uenoidae) in two Northern California streams. Ann. Entomol. Soc. Am., 101, 573-584.

Morais P., 2008. Review on the major ecosystem impacts caused by damming and watershed development in an Iberian basin
(SW-Europe): focus on the Guadiana estuary. Ann. Limnol.Int. J. Lim., 44, 105-117.

Mouthon J. and Daufresne M., 2006. Effects of the 2003 heatwave and climatic warming on mollusc communities of the Saône: a large lowland river and of its two main tributaries (France). Glob. Chang. Biol., 12, 441-449.

Nicholls C.I., Parrella M. and Altieri M.A., 2001. The effects of a vegetational corridor on the abundance and dispersal of insect biodiversity within a northern California organic vineyard. Landsc. Ecol., 16, 133-146.

Ode P.R., 2007. Standard operating procedures for collecting macroinvertebrate samples and associated physical and chemical data for ambient bioassessments in California. California State Water Resources Control Board Surface Water Ambient Monitoring Program (SWAMP) Bioassessment SOP 001.

Orang M.N., Matyac J.S. and Snyder R.L., 2008. Survey of irrigation methods in California in 2001. J. Irrigat. Drain. Eng., 134, 96-100.

Poff N.L., Olden J.D., Vieira N.K.M., Finn D.S., Simmons M.P. and Kondratieff B.C., 2006. Functional trait niches of North American lotic insects: traits-based ecological applications in light of phylogenetic relationships. J. N. Am. Benthol. Soc., 25, 730-755.

Rehn A.C., Ode P.R. and May J.T., 2005. Development of a benthic index of biotic integrity (B- IBI) for wadeable streams in northern coastal California and its application to regional 305(b) reporting. California State Water Quality Control Board, Sacramento, California.

Smith R.J., Klonsky K.M., Livingston P.L. and DeMoura R.L., 2004. Sample costs to establish a vineyard and produce wine grapes: North Coast region, Sonoma County. University of California Cooperative Extension, Davis, California.

Spooner D.E. and Vaughn C.C., 2008. A trait-based approach to species' roles in stream ecosystems: climate change, community structure, and material cycling. Oecologia, 158, 307-317.

Tornés E., Cambra J., Gomà J., Leira R., and Sabatar S., 2007. Indicator taxa of benthic diatom communities: a case study in Mediterranean streams. Ann. Limnol. - Int. J. Lim., $43,1-11$. 